\title{
研究部 会報告
}

農業気象 (J. Agr. Met.) 48 (3): 295-297, 1992

\section{シンポジウム「農業限界地における気象改良」}

\section{耕地気象改善研究部会}

第 5 回耕地気象改善研究部会

日 時：1992 年 7 月 3 日(金)

場 所：岩手大学農学部

1. 中国の半乾燥地域における節水・耐風農耕

農業環境技術研究所：原䄇芳信

2. 中国北西部の乾燥農業限界地域の気象改良事例

熱帯農業研究センター：真木太一

3. 乾燥地の牧農業開発と保全対策

鳥取大学乾燥地研究センター：神近牧男

座 長

弘前大学農学部藏健治

果樹試験場盛岡支場 鴨田福也

\section{部 会 長 挨 拶}

熱帯農業研究センター環境資源利用部 真木太一

先月, ブラジルのリオデジャネイロで, 127 ケ国の参 加のもとに開催されました地球サミット「環境亡開発に 関する国連会議」（21世紀に向けての地球環境の保全策 の政府間会議）につきましては，まだ皆様の記憶に新し いととと思います。地球環境を守る憲法「リオ宣言」と その実行計画「アジェンダ21」が採択されました。との 中には人口問題解決, 貧困打開, 森林保全, 砂漠化防止, 野生生物保護, オゾン層破壊防止, 大気・海洋污染防止 等々の計画が含まれています。また，法律・条約関係で は「地球温暖化防止条約」,「生物多様性条約」の二つが 新たに調印され，さらに「森林原則声明」とアフリカか ら出された「砂漠化防止条約」の交渉会議の設置要請が 盛り込まれました。

生物多様性条約では米国は終始反対にまわり，また日 本も最初は反対にまわっていましたが，イギリス，フラ ンスなどに押されてしぶしぶ調印するととになりました。 そして $\mathrm{CO}_{2}$ 抑制についてあ同様な態度を取りました。い ずれにしましても, 今回の地球サミットは一定の成果を 収めたてとと思います。

そして, 砂漠化防止条約については，乙の秋から検討 が始まるととと思います。本研究会では，乙の砂漠化防
止に関連のある研究課題を取り上げました。

ところで, 本研究部会は名称変更，すなわち農業気象 災害研究部会加ら耕地気象改善部会に名称变更して 3 年 になりますが，今までは耕地気象改善についてトピック ス的な課題のもとで研究会が開催されましたが，今回か ら数回は「農業限界地に扔ける気象改良」として限界地 農業について研究会を持つととになりました。今回は乾 燥地, 砂漠の問題を取り上げて, 中国を中心に世界の代 表的な乾燥地域に抢ける気象改良事例を紹介してもらい ます。活発な討論をお願いいたします。

なお，次回は関東支部との共催で11月に電力中央研究 所で開催する予定です。奮って御参加下さい。

最後に, 本研究会の参加者抢よび研究会開催に協力い ただきました方々に，心よりお礼申し上げます。よ゙うむ ありがとうございました。

\section{1. 中国の乾燥地における節水農業に見る 微気象改良技術}

\section{農業環境技術研究所 原薗芳信}

中国の乾燥地域におりる節水農業を現地調查した。対 象地は, 半乾燥地である内モンゴル東部の奈曼, 寧夏回 族自治区中衛，甘肃省蘭州周辺，そして甘肃省西部オア シスの敦煌である。現地の節水農業にみられる微気象改 良技術を，湿潤地域の農業と比較した。

乾燥地では, 月平均最高気温は 8 月に約 $30^{\circ} \mathrm{C}$ まで昇 するが日最低気温は夏季でも $18^{\circ} \mathrm{C}$ 程度で, 冬季はー $20^{\circ} \mathrm{C}$ 程度に低下する。降水は 6 ～8月に多く，年降水量の 60 〜 80\%がての 3 力月間に降り, 秋季から春季には少ない。 冬季加ら初夏には西風か強く，大陸内部や付近の砂漠か らの飛砂が激しくなる。強風のため日射量の多い7，8月 より 4 月 6月の蒸発量が多く, 年蒸発量は $1740 \mathrm{~mm}$ に 達し，日本の平均的な湖沼の蒸発量の 2 倍以上である。

てれらの気象条件は，作物の植え付け時期降水量が 少なく蒸発量が多いという栽培にとって厳しい条件とな る。また，栽培期間を通して降水量が絶対的に不足する 乙とから，天水だけに頼る農業生産の限界があり，地下 水や灌溉用水を利用できる所では，土㗧への塩類集積の 
危険がある。冬季には乾燥と低温のため，永年性作物や 果樹などに対する凍害の発生が懸念される。

中国の乾燥地域で実施されている微気象改良に係わる 農耕技術は以下のように要約できる。

1）蒸発量が多いととから塩類集積の危険があり，乙 れに対処する灌溉技術として $2 \sim 3$ 週間毎に嘎場を湛水 する湛水灌溉が用いられる。

2）落葉樹による防風・遮光林を設け，夏季には蒸発 抑制のために日射量を多少儀牲にしても遮光を行う。オ アシスの農耕地, 水稲栽培地域や灌溉農業を行っている 地域では道路や畦道, 用水路の両側に並木を植え, 都市 近郊では果樹や落葉樹の緑陰で野菜栽培を行い, 日射遮 蔽と地表付近の風速を低下させて蒸発散量を抑制してい た。

3）フィルムや小石などを用いたマルチにより土壤か らの蒸発量を減らす。フィルムマルチは都市近郊では広 く普及し，施設栽培化が進行していた。小石を用いるス トーンマルチは黄土高原一帯で広く用いられており，保 温と種子や土壌の風蝕対策を兼ねていた。

4) オアシスでは，不必要な植物の生育を止め（生長 点の切除）蒸発散を減らす。また, 収穫直後に耕起し雑 草の生育を止めると同時に，毛管水を遮断するてとによ る蒸発抑制と塩類の析出を防止していた。オアシスでは, 利用可能な水量が限られるため, 耕地の輪作 (約 $1 / 3$ は 休耕）により地力維持と水利用効率の向上を図っている。

5）砂丘周辺の無灌溉農耕地では，乾燥と貧栄養条件 に而性のある在来品種(ソバ, ソルガムなど)を用い, 降 雨直後の発芽を利用して穀物収穫を図る。

現地調查は科技庁振興調整費総合研究により実施した。 便宜を図って頂いた関係各位に感謝する。

\section{2. 中国北西部の乾燥農業限界地域の 気象改良事例}

熱帯農業研究センター環境資源利用部 真木太一

（1）砂漠化の現状： 最近，世界的にマスコミを騷が せている環境問題に地球温暖化, 砂漠化, 森林破壊, 酸 性雨，オゾン層破壊などがあるが，乙こでは主として砂 漠化，植生破壊に関連深い問題を取りあげ，中国北西部 の新疆における事例を中心に解説し，エジプトなどにつ いても若干触れた。中国における砂漠化は，すでに相当 広範囲に及んでいる。近年砂漠化した地域の面積は17万 $\mathrm{km}^{2}$ 亿達する。また砂漠化進行速度は $1500 \mathrm{~km}^{2} /$ 年であ り, 今後砂漠化の可能性のある地域は 16 万 $\mathrm{km}^{2}$ に及ぶ。 砂漠化 (desertification) の定義は, 国連砂漠化防止会議 の「土地の持つ生物の潜在的生産力の低下か, 破壊であ り，最終的には秒漠のような状態になる現象」である。
（2）オアシスと気象改良：砂漠化の原因には自然的 要因と人為的要因がある。中国の乾燥地の人為的要因に よる砂漠化は主として過放牧, 過開懇, 過伐採, 過消費 による。オアシス, 緑州の典型は林に囲まれた土地であ り, 乾燥地域のオアシスは防風林, 防砂林がないあのは ありえないと言っても過言ではない。

（3）防風施設に上る気象改良効果：タマリスク防風 林は密閉度が高いわりに葉が細かいため, 減風効果が大 きい。また乾燥地での気象改良効果として, 夏季の加湿 効果があり，日中の過昇温はあまり大きくない。さらに 風食防止効果が大きい特徴がある。しかむ砂に埋まると 伸長する特徵があり, 高さ $10 \mathrm{~m}$ 程度になる。タマリスク は耐干, 耐風, 耐熱, 耐寒, 耐塩性が大きく, 農業限界 地においては非常に優れた防風林である。次に，防風ネ ットは種類が多く減風効果, 種々の目的のあのが得られ, ネット設定による速効性があるが，夏季，日中には防風 ネット付近での過昇温と乾燥化が防風林より大きい。そ の他，草方格による減風，被覆性は有効である。

（4）防風施設以外の気象改良技術：灌溉法による気 象改良, 被覆法による気象改良, 水食・風食防止による 気象改良，塩類集積防止などについて述べた。

（5）自然エネルギーの有効利用：乾燥地では資源を 有効利用する必要がある。特に砂漠では降水量が少なく 水資源は少ないが, 晴天は多く, 日射量, 太陽エネルギ 一は豊富であり, 一般に強風地域が多いため, 風力エネ ルギーの利用あ可能である。乙の太陽・風力エネルギー はサステーナブルな再生可能なエネルギーとして持続的 に利用できる。現在よく言われるクリーンなエネルギー で砂漠での気象資源として大いに活用すべきである。

\section{3. 乾燥地の牧農業開発と保全対策}

鳥取大学乾燥地研究センター 神近牧男 乾燥地に住む人々は，厳しい自然条件のむとで糧を得 て生活している。中国内蒙古自治区の毛烏素砂漠は, か つては豊かな草原であったと言われるが，薪炭の取り過 ぎ，過放牧，農耕の進出と耕地の放棄などにより砂漠化 が進行した。現在，乙の土地に住む牧農民は，定住化政 策により 1戸あたり 200 300 ha の土地を有し, 砂漠化 の脅威と地域開発の課題を背負っている。砂漠化防止之 牧農業開発が永続性を持って継承されていくためには, 行政的なとり組みだけでなく，現地に住む人々の主体的 とり組みが不可欠であると考える。そこで，乙てでは毛 鳥素砂漠の牧農社会の構成単位である牧農家について, 1 戸あたり所有地の土地利用状況をモデル化し，起生す る種々の災害と保全の課題をリストアップする。 毛烏素砂漠中央部の鳥審召気象観測所の 20 年平均值に 
よれば，年降水量は $360 \mathrm{~mm}$ あり，その約 7 割は 7 \%

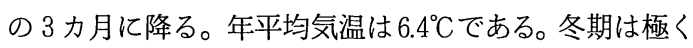
寒冷で, 11 3月にかけて土壌は凍結する。反面, 5 ～ 9 月は無霜期間で， 7 月の月平均気温は $20^{\circ} \mathrm{C}$ を上回るな ど気温の年変動が著しい。春を中心とした 3〜 6月には, 最大風速が $17 \mathrm{~m} / \mathrm{s}$ を越える暴風日が多発する。

高緯度乾燥地に特有のてれらの気象条件は, 牧農業に とって数々の制約や災害をもたらし，砂漠化した土地の 植生回復を困難にしている。しかしながら，年間日照率 が 70\%を越えるとと，暖候期に降水量が多い等の気候条 件は，その利用次第で効率的な砂漠化防止，農業開発が 可能であるてとを示している。

牧農家の土地利用は, 現状では次の 4 段階に類型化で きる。すなわち，1. 砂漠化したままで放置され利用さ
れない地域 2. 天然の草地で家畜の放牧に利用される 地域 3. 人工的に管理される牧草地 4 . 住居近くで 自給的な生産が行われる耕作地, であり, 将来的には, 5. 農産物の供給基地として集約的な生産が行われる農 園地，がある。それぞれの土地利用レベルにおいて，克 服すべき保全, 開発上の課題には内容的に大きな相違が あると考えられる。個々の牧農家段階で考えると, ての ような土地利用の比重に応じた可能な保全策・管理策を 模索・確立・実施しなければならない。同様に, 牧農社 会段階から，総合的な地域開発に至るまでの過程におい ては，それぞれの開発レベルに応じて必須となる保全， 管理策が存在するといえる。乾燥地の砂漠化防止と牧農 業開発は, とり組む主体と対象となる課題と将来像を明 確に捉え，きめ細かに環境改良を設計する必要がある。 